\title{
Design principles for hybrid learning configurations at the interface between school and workplace
}

\author{
Petra H. M. Cremers ${ }^{1}$ - Arjen E. J. Wals ${ }^{2} \cdot$ Renate Wesselink $^{2}$ • \\ Martin Mulder ${ }^{2}$
}

Received: 26 September 2014/ Accepted: 4 May 2016/Published online: 23 May 2016

(C) The Author(s) 2016. This article is published with open access at Springerlink.com

\begin{abstract}
In today's knowledge society, there is a demand for professionals who are able to create knowledge across boundaries of disciplines, professions and perspectives. Traditional universities, universities of applied sciences and institutions for vocational education are all challenged to educate these knowledge workers. Accordingly, these institutions are developing competence-based education programmes that promote authentic, self-directed learning and the development of a professional identity. A possible environment for realising this type of learning is the hybrid learning configuration in which learning is embedded in ill-defined and highly-authentic tasks. This study attempted to identify a set of principles that can underpin the design of such a learning configuration at the interface between school and workplace. The research approach consisted of educational design research. Starting from cognitive constructivist and socio-cultural perspectives, a set of initial design principles was developed and evaluated from the perspective of the participants during three consecutive iterations of design and implementation. The process resulted in a set of seven refined design principles which can be used as heuristics to guide the design and development of hybrid learning configurations in contexts that have similar goals and aligned tenets.
\end{abstract}

Keywords Authentic learning · Educational design research · Hybrid learning configuration · University of applied sciences · Vocational education

Petra H. M. Cremers

p.h.m.cremers@pl.hanze.nl

1 Staff Office Education and Applied Research, Hanze University of Applied Sciences Groningen, P.O. Box 30030, 9700 RM Groningen, The Netherlands

2 Education and Competence Studies, Wageningen University, P.O. Box 8130, 6700 EW Wageningen, The Netherlands 


\section{Introduction}

In today's knowledge society (Hargreaves 2003), there is a demand for professionals who are able to create knowledge collaboratively across boundaries of disciplines, professions and perspectives (Engeström 1999; Paavola et al. 2004). Traditional universities, institutions for postsecondary vocational education and universities of applied sciences are all challenged to educate these 'knowledge workers' (Kessels 2001).

Accordingly, these institutions have developed competence-based study programmes that are intended to facilitate the development of comprehensive vocational competence. Many researchers claim that effective competence-based education should promote selfdirected and authentic learning both within and beyond the workplace (e.g. De Bruijn and Leeman 2010; Wesselink et al. 2010). In addition, by participating in a working community, students are given the opportunity to develop a professional identity (Billett and Somerville 2004; De Bruijn and Leeman 2010).

Because some features of a working practice cannot be experienced or practised exclusively in a school environment (Billett 2002), most programmes in vocational education offer students workplace experience, for instance by incorporating internships into their curriculum. Billett (2002) and Poortman (2007), however, claim that participation in a workplace setting has certain limitations and does not always facilitate effective learning.

Educational institutions have addressed these limitations by improved connectivity between school and workplace (Tynjälä 2009). In this way, they seek to bridge the gap between both theory and practice and on-campus and off campus learning. Examples of such 'cooperative education strategies' (Zegwaard and Coll 2011) are the connective model of work experience (Guile and Griffiths 2001) which provides a new curriculum framework that can take work in all its forms as the basis for the development of knowledge, skills and identity, and the integrative pedagogy model (Tynjälä 2008) which connects conceptual theoretical, practical and self-regulative knowledge.

In this study, we were interested in connecting school-based learning and work experience by interweaving learning and working processes in one setting: the so-called 'hybrid learning configuration'. Wals, Lans and Kupper (2012) define a hybrid learning configuration (HLC) as a social practice around ill-defined, authentic tasks or issues whose resolution requires transboundary learning (e.g. by transcending disciplines, traditional structures and sectors, and forms of learning). We focus on HLCs that are situated at the interface between school and workplace in which working and learning are integrated as students work on assignments from clients or other stakeholders in the community (Huisman et al. 2010; Zitter 2010; Zitter and Hoeve 2012).

HLCs share characteristics with 'context-based learning environments' (de Putter-Smits et al. 2013), 'powerful learning environments' (De Bruijn and Leeman 2010) and 'authentic learning environments' (Herrington and Oliver 2000) in the sense that they seek to promote self-directed and authentic learning and the development of a professional identity.

Although there is a growing body of mostly conceptual literature emphasising the importance of hybrid learning, there have not been many empirical studies of the design and implementation of such learning. The goal of this study was to fill this lacuna by identifying a set of principles that can underpin the design of HLCs.

An educational design project called Value in the Valley provided the context for this study. In this project, a learning environment was developed that had the characteristics of a HLC at the interface between school and workplace. The participants came from four 
different educational institutions and two companies. The students' learning was supported as they were tasked with solving complex problems related to sustainability issues for clients in the community (ill-defined authentic tasks that require transboundary learning).

In the next section, we describe this project in detail. In the following sections, we explain the educational design research (EDR) approach that was adopted and address the main research stages. Finally, we discuss conclusions drawn from the research.

\section{Research context: value in the Valley}

The educational design project Value in the Valley was initiated by two Dutch institutions for senior-secondary vocational educational (which are called 'MBO' in Dutch) and two universities of applied sciences ('HBO' in Dutch) in collaboration with two companies. The project aimed to address an increasing demand from industry and business for professionals who are able to contribute to sustainability-driven multidisciplinary and multisector innovations. The somewhat vague term 'sustainability-driven' refers to innovations seeking to develop business models, processes and products that are more capable in balancing ecological, environmental, ethical and socioeconomic interests than those they seek to modify or replace. Conventional study programmes (at MBO and HBO levels) are typically not aimed at educating this kind of knowledge worker. Questions to be addressed in the project were: "How should a learning configuration be designed and implemented so that it contributes effectively and efficiently to the development of capable and innovative professionals?" and "How can this configuration (or parts of it) be implemented in other educational institutions or other organisations?" (Antonides and Hoetink 2005).

In order to answer the first question, an HLC was designed, implemented and evaluated in six iterations of one semester each. The learning configuration represented an authentic working context in the sense that it functioned as a consultancy firm in which assignments were carried out for companies and governmental institutions in the region. It was located at a business park. Students from the participating schools were the junior employees. The faculty, lecturers and educational consultants from the participating educational institutions, as well as employees from the participating companies, acted as the senior employees. They coached, instructed and guided the students while they worked on the assignments. Most of the faculty worked part time at the Value in the Valley project and spent the rest of their time at their own educational institution or their company.

Participants included students enrolled in several different study programmes, mostly from the technical and 'green' (e.g. agricultural, environmental, land-use planning) sectors in $\mathrm{MBO}$ and $\mathrm{HBO}$. The number of students varied in each iteration and ranged from 15 to 35. The students worked in multidisciplinary and 'multi-level' (MBO and HBO) teams on real-life assignments that involved issues of sustainability. For example, in the 'Sustainable village' assignment, a step-by-step strategy was developed for villages to become a sustainable community and, in the 'Rain in Groningen' assignment, ideas were developed for the temporary storage of excessive rain that is predicted in local climate change scenarios.

Students spent one semester at Value in the Valley, with the programme replacing a part of their regular curriculum (e.g. an internship or regular course). The faculty performed formative assessments at regular times during the semester. The summative assessment and assignment of study credits were conducted by lecturers within the students' own study programme. 


\section{Educational design research}

The research approach chosen for this study was EDR. Design research is especially useful when existing knowledge about a certain phenomenon is wanting as is often the case with highly innovative curriculum improvement initiatives (McKenney and Reeves 2012).

The research project started from a problem in educational practice. This problem was analysed and a tentative solution was designed that combined existing theory, practical knowledge and experience (craft wisdom) and creative inspiration (McKenney and Reeves 2012). This solution was implemented in practice and evaluated in three iterations.

The theoretical output of this study takes the form of an empirically tested set of design principles or heuristics that can be used to guide endeavours that have similar goals and aligned tenets (McKenney and Reeves 2012). Sandoval (2014) refers to design principles as 'high-level conjectures' which are reified in features of the learning environment design. Design principles can be theory-driven or constructed inductively from empirical findings (Lakkala et al. 2012).

Design research can be characterised as interventionist, iterative, process oriented, utility oriented and theory oriented (Van den Akker et al. 2006). It is not aimed at measuring isolated variables but at capturing integral and meaningful phenomena in a naturalistic setting. In this study, only one manifestation of a certain phenomenon, namely, an HLC, was studied. Therefore, it contributes theoretical understanding that is closely tied to the problem at hand, thereby yielding 'local theory' (McKenney and Reeves 2012). Consequently, this study did not strive for context-free generalisations: "Design principles are not intended as recipes for success, but to help others select and apply the most appropriate substantive and procedural knowledge for specific design and development tasks in their own settings" (McKenney et al. 2006, p. 73).

In order to describe the EDR approach used in this study, a model was created (see Fig. 1) that combines relevant features of existing models by Andriessen (2007), Wals and Alblas (1997) and McKenney and Reeves (2012). Four main stages can be discerned in the model. They were carried out as follows:

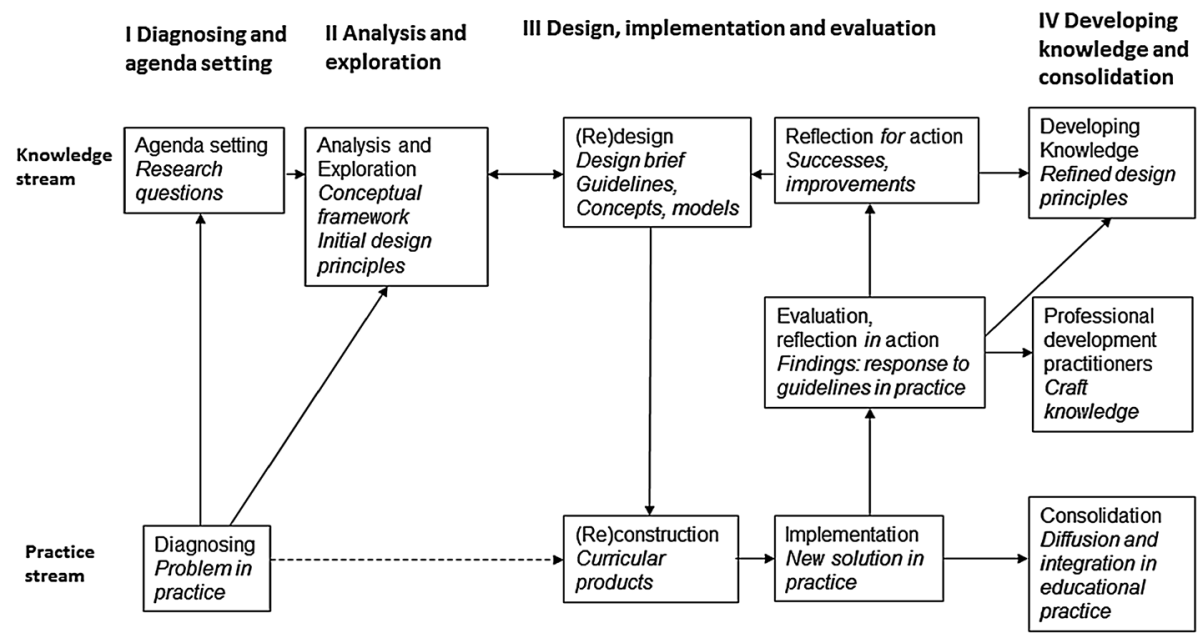

Fig. 1 Model for educational design research based on Andriessen (2007), McKenney and Reeves (2012) and Wals and Alblas (1997) 
1. Diagnosing and agenda setting. The problem in practice that was derived from the project plan was translated into the research question and the formulation of desired outcomes or learning processes.

2. Analysis and exploration. Researcher and practitioners collaboratively developed a conceptual framework that underpinned the design of the learning configuration. Craft knowledge from experienced practitioners was elicited and a literature search was conducted. This resulted in a set of initial design principles.

3. Design, implementation and evaluation. For this study, three iterations of the learning configuration were evaluated in order to explore how, from the perspective of the participants, the initial design principles manifested themselves in practice. Design principles become more useful for designers when they are connected with features that exemplify how the principles can be applied in different contexts (Kali 2006). Therefore the manifestation of each design principle was described in terms of these features and their effects on the participants. This resulted in a set of refined design principles.

4. Developing knowledge. The research question was answered by drawing conclusions from the manifestations of the refined design principles, thus linking their enactment to the desired learning processes. What follows is a detailed description of all four stages of this research approach.

\section{Stage I: diagnosing and agenda setting}

According to the project plan (Antonides and Hoetink 2005), the objectives of Value in the Valley were of a very practical nature (reflecting the practice stream; see Fig. 1):

- an effective and efficient learning configuration that educates innovative, sustainability professionals (see also Wierenga et al. 2010),

- professional development of the participating faculty,

- design briefs, concepts, models, tools and instruments to be used for implementation in other contexts.

Based on this last objective, the project team and the researcher chose to develop a set of theory- and practice-based design principles for the HLC and formulated the central research question in the knowledge stream (Fig. 1): "Which set of principles can underpin the design of a hybrid learning configuration for educating the knowledge worker?"

A further operationalisation of the 'HLC for the knowledge worker' can be expressed by taking into account the learning processes that it is intended to trigger. As described in the introduction, the HLC seeks to enable self-directed learning, authentic learning and the development of a professional identity. In addition, it is aimed at educating knowledge workers, who create new knowledge collaboratively across the boundaries of disciplines, professions and perspectives.

\section{Stage II: developing initial design principles}

The objective of this phase was to develop a set of initial design principles. First we introduce the method used to develop these principles. Next, we present the conceptual framework underlying the design, which can be viewed as the 'epistemology of the designers' or the designers' perspective on learning (Kali et al. 2009). We conclude by describing how the design principles were derived from this framework, which links them to the key concept(s) that they represent. 


\section{Method}

The initial design principles were developed collaboratively by the researcher and the Value in the Valley faculty consisting of lecturers, educational consultants and business representatives. Because of this collaborative approach, we were able to draw on expertise and knowledge from both an educational and a business perspective (Könings et al. 2007). An additional benefit of this approach is that the practitioners' involvement in the design encouraged their agency in the implementation of the designed intervention (i.e. the HLC) (Bronkhorst et al. 2013).

The method used to arrive at a set of initial design principles consisted of the construction of a conceptual framework from which the principles could be derived. This was accomplished by eliciting craft knowledge from experienced practitioners and by a literature search. Because the HLC aimed to interweave working and learning processes, existing literature on work-based learning and educational theory was studied. This was combined with and validated by personal experiences and observations in educational and working practice by the Value in the Valley faculty. External educational experts were also consulted, and two educational researchers who were not involved in the project were asked to comment on the initial design principles. Their questioning of the exact meaning of each principle led to a more-detailed and more-focused description of the principles. This description was confirmed and approved of by Value in the Valley faculty. By the end of iteration 3 of the HLC, a set of nine initial design principles had emerged.

Internal validity or a high 'truth value' (Guba 1981) was ensured by reaching consensus among the Value in the Valley faculty about the set of initial principles. External validity was enhanced by consulting external experts (e.g. from educational consultancy firms) during the development of the initial design principles and by involving external educational researchers.

\section{Conceptual framework}

One central function of the conceptual framework was to underpin the integration of educational and working activities. In order to do justice to each of the worlds of education and work, both cognitive constructivist and socio-cultural perspectives on learning were taken. The cognitive constructivist point of view emphasises the active role of the student and the integration of theoretical and practical knowledge (Bromme and Tillema 1995; Tynjälä 1999). From the point of view of socio-cultural and situated learning theories, it is important that education involves students in authentic practices and social interaction (Brown et al. 1989; Lave and Wenger 1991).

Sfard (1998) introduces two metaphors of learning that relate to these points of view. The acquisition metaphor refers to an individual's cognitive knowledge construction, whereas the participation metaphor refers to the socio-cultural view of learning. These metaphors are both helpful in coming to understand and support learning processes, and they can be seen as complementary (Billett 1996; Sfard 1998). Thus, Sfard's metaphors constitute a promising framework in which to develop expertise at the interface of education and work (Tynjälä et al. 2003).

This framework has been further developed by Illeris (2002), whose model integrates the two learning metaphors as the processes of acquisition and interaction that take place within the following three dimensions of learning: content, incentive and environment. The content dimension concerns what is learned and how meaning is given. The incentive dimension involves motivation, emotion and volition. The environment dimension, which 
is also called the 'interaction dimension', is characterised by action, communication and cooperation within relevant social contexts and communities. These three dimensions "...must always be considered if an analysis or an understanding of a learning situation is to be adequate" (Illeris 2002, p. 25).

The acquisition and participation metaphors (Sfard 1998) and the three dimensions of learning — cognition, incentive and environment (Illeris 2002)—were the starting points for the development of the initial design principles in this study.

\section{Design framework}

The design framework was developed via further elaboration of the conceptual framework. This resulted in the set of nine initial design principles summarized in Table 1.

Within the participation metaphor, the concepts of 'situated learning' (Lave and Wenger 1991) and 'situated cognition' (Brown et al. 1989) refer to the importance of an authentic context for learning. Many researchers emphasise the importance of engagement in authentic practice in vocational education programmes in order to develop the students' occupational capacities (e.g. Billett 2011). Hence the first design principle is fostering authenticity.

The participation metaphor is also reflected in the concepts of the knowledge-building community and the community of learners (Brown and Campione 1996; Rogoff et al. 1996; Scardamalia and Bereiter 1993). Lave and Wenger (1991) suggest that learning through work experience often occurs by participating in a 'community of practice' in which individuals learn through contact with more-experienced others. Within a community of learners, both experienced and less-experienced participants have active roles, and learning becomes a shared endeavour. According to Rogoff et al. (1996), participants in such a learning community appear to take responsibility both for managing their own learning and for supporting and leading others. Hence the second principle is creating a learning community.

Learning from participation in a workplace setting depends both on the extent to which opportunities for participation (i.e. affordance) are provided and the extent to which individuals choose to utilise these opportunities (i.e. agency) (Billett 2004). Eteläpelto et al. (2013) argue that both active participation and agency at work are prerequisites for workers to become creative lifelong learners who actively develop work practices with colleagues. Billett (2011) uses the term 'agentic learners' in this respect. Therefore students should develop a sense of responsibility for themselves and their environment as they gradually take more ownership. This was captured in the third principle: increasing ownership.

The ability of the knowledge worker to solve problems in an interdisciplinary context should be reflected in the learning configuration. Gibbons et al. (1997) refer to this as 'Mode 2 knowledge production', which is context-driven, problem-focused and interdisciplinary. Guile and Griffiths (2001) argue that workers are increasingly expected to be competent 'boundary crossers'. Walker and Nocon (2007, p. 181) describe 'boundary-crossing competence' as the "ability to manage and integrate multiple, divergent discourses and practices across social boundaries." According to Akkerman and Bakker (2011), boundary crossing requires not only the ability to understand and learn from each other's perspectives, but also the capability to effectively transform practices and perspectives. This transformation involves a creative process of building new knowledge, referred to by Sawyer (2004) as 'collaborative emergence'. The importance of making optimal use of different practices and perspectives was expressed in the fourth design principle: utilising diversity.

According to Kessels (2001), an authentic working environment for knowledge workers should enhance and support learning processes. Along these lines, Tynjälä (2008) proposes 
that learning environments should be created in which conceptual, practical and selfregulative knowledge are present and become interconnected. However, as Griffiths and Guile (2003) argue, learners should be assisted in the process of connecting knowledge, skills and experience. Billett (2002, p. 29) confirms this by suggesting that "the use of intentional guided learning strategies has demonstrated a capacity to augment the contributions of everyday experiences by making accessible and developing understanding and procedures that are unlikely to be learned alone". The corresponding fifth principle is interlinking of working and learning.

A relevant theory within the cognitive dimension of learning (Illeris 2002) is the concept of learning by both participating in authentic activities and reflecting on them. This is captured in Kolb's reflective cycle (Kolb 1984) and Schön's notion of the 'reflective practitioner' (Schön 1987). In more recent models for improving connectivity between school-based and workbased learning, reflection is linked to the integration of practical and theoretical knowledge (e.g. Tynjälä 2008; Guile and Griffiths 2001). Given the situated nature of work-based learning, learners should be supported in the process of analysing their own experiences and arriving at a critical understanding of their reality (Guile and Griffiths 2001). On the basis of these notions, the sixth principle was formulated as facilitating reflection.

The incentive dimension of learning (Illeris 2002) can be related to Damasio's research into the role of emotions in social cognition and decision-making (Damasio 1994). It can be assumed that positive emotions foster self-regulation (Pekrun and Linnenbrink-Garcia 2012) and enhance the development of a vocational identity by the learner (Meijers and Wardekker 2001). Strauser et al. (2008) found a positive effect of psychological well-being on the development of a vocational identity which they described as the process through which individuals become aware of their career interests, goals, skills and talents. This supports the notion that the individual talents, interests and motivations of each student are important for their professional development and would have to be addressed explicitly within the learning configuration. This notion was expressed in the seventh principle: enhancing individual talents.

The eighth principle relates to assessment considered as an important part of the learning process. Many researchers state that assessment methods should support and enhance students' learning (Gibbs and Simpson 2004; Tynjälä et al. 2003). They argue that students should receive formative assessments at regular times during the learning period, instead of receiving only a summative assessment at the end of the learning period. Van Merriënboer and Sluijsmans (2009) propose that regular provision of feedback and 'feed forward', or reflection and 'preflection', can enhance self-directed learning. Boud (2007, p. 21) claims that assessment should be focused on "monitoring one's own performance, to see one's own learning in the context in which it is deployed and to respond with awareness of the exigencies of the tasks in which one is engaged". This idea was captured in the eighth principle of assessing for learning. (This term was inspired by Mentkowski, Doherty, Loacker, Hart, Richards, O'Brien (...) and Cromwell 2000.)

A final, more-overarching principle emerged after considering the other eight. In order for all of the other principles to apply, the learning configuration must have an organisational structure that supports the inter-linked working and learning processes. Concepts of the learning organisation (Senge 1990) or the 'hybrid organisation' (Nonaka and Takeuchi 1995) inspired the ninth design principle, which is called enabling organisation.

\section{Initial design principles}

In Table 1, the initial design principles are described and examples of their manifestations in practice are given. 
Table 1 Initial design principles, descriptions and manifestations

\begin{tabular}{lll}
\hline $\begin{array}{l}\text { Design } \\
\text { principle-key } \\
\text { concept }\end{array}$ & $\begin{array}{l}\text { Design principle- } \\
\text { description }\end{array}$ & $\begin{array}{l}\text { Examples of manifestations } \\
\text { within the learning } \\
\text { configuration }\end{array}$ \\
\hline
\end{tabular}

\begin{tabular}{|c|c|c|c|}
\hline $\begin{array}{l}\text { 1. Fostering } \\
\text { authenticity }\end{array}$ & $\begin{array}{l}\text { Participants work and learn } \\
\text { in an environment } \\
\text { (context, tasks, activities, } \\
\text { roles and } \\
\text { communication) that } \\
\text { reflects working practice, } \\
\text { a professional working } \\
\text { culture and organisation }\end{array}$ & $\begin{array}{l}\text { Working for real clients } \\
\text { from industry and other } \\
\text { organisations } \\
\text { Students, educators, } \\
\text { consultants and experts } \\
\text { from working practice are } \\
\text { seen as employees and } \\
\text { relate to each other as } \\
\text { (junior and senior) } \\
\text { colleagues }\end{array}$ & $\begin{array}{l}\text { Billett (2011); Brown et al. } \\
\text { (1989); Lave and Wenger } \\
\text { (1991) }\end{array}$ \\
\hline $\begin{array}{l}\text { 2. Creating a } \\
\text { learning } \\
\text { community }\end{array}$ & $\begin{array}{l}\text { Community: Every } \\
\text { member should } \\
\text { experience a sense of } \\
\text { belonging to the } \\
\text { community } \\
\text { Learner equity: Every } \\
\text { member of the } \\
\text { community is a learner, } \\
\text { each at his/her own level }\end{array}$ & $\begin{array}{l}\text { A culture of respect, } \\
\text { equality and curiosity } \\
\text { that stimulates learning is } \\
\text { fostered } \\
\text { Learning trajectories for } \\
\text { junior and senior } \\
\text { participants are similar } \\
\text { and run parallel } \\
\text { Members participate in } \\
\text { communities that include } \\
\text { experts and professionals }\end{array}$ & $\begin{array}{l}\text { Brown and Campione } \\
\text { (1996); Illeris (2002); } \\
\text { Lave and Wenger (1991); } \\
\text { Rogoff et al. (1996); } \\
\text { Scardamalia and Bereiter } \\
\text { (1993) }\end{array}$ \\
\hline $\begin{array}{l}\text { 3. Increasing } \\
\text { ownership }\end{array}$ & $\begin{array}{l}\text { Participants are } \\
\text { increasingly responsible } \\
\text { for their own learning, } \\
\text { functioning, personal } \\
\text { well-being and give-and- } \\
\text { take. Reciprocity in } \\
\text { information exchange } \\
\text { and effort }\end{array}$ & $\begin{array}{l}\text { Learners work on } \\
\text { assignments of increasing } \\
\text { complexity } \\
\text { Senior and junior } \\
\text { participants share the } \\
\text { responsibility for the } \\
\text { physical and social } \\
\text { working environment }\end{array}$ & $\begin{array}{l}\text { Billett (2004, 2011); } \\
\text { Eteläpelto et al. (2013) }\end{array}$ \\
\hline $\begin{array}{l}\text { 4. Utilising } \\
\text { diversity }\end{array}$ & $\begin{array}{l}\text { Diversity is built-in, valued } \\
\text { and utilised both at team } \\
\text { and organisational levels } \\
\text { and in internal and } \\
\text { external networks }\end{array}$ & $\begin{array}{l}\text { Multidisciplinary teams } \\
\text { collaborate with peers } \\
\text { and are informed by } \\
\text { internal and external } \\
\text { experts } \\
\text { Senior participants from } \\
\text { different companies, } \\
\text { study programmes and } \\
\text { educational levels } \\
\text { collaborate in the design, } \\
\text { implementation and } \\
\text { evaluation of the learning } \\
\text { configuration } \\
\text { Assignments from clients } \\
\text { require an } \\
\text { interdisciplinary } \\
\text { approach that matches } \\
\text { the disciplines of the } \\
\text { team members }\end{array}$ & $\begin{array}{l}\text { Akkerman and Bakker } \\
\text { (2011); Gibbons et al. } \\
\text { (1997); Guile and } \\
\text { Griffiths (2001); Sawyer } \\
\text { (2004); Walker and } \\
\text { Nocon (2007) }\end{array}$ \\
\hline
\end{tabular}


Table 1 continued

\begin{tabular}{|c|c|c|c|}
\hline $\begin{array}{l}\text { Design } \\
\text { principle-key } \\
\text { concept }\end{array}$ & $\begin{array}{l}\text { Design principle- } \\
\text { description }\end{array}$ & $\begin{array}{l}\text { Examples of manifestations } \\
\text { within the learning } \\
\text { configuration }\end{array}$ & Conceptual grounding \\
\hline $\begin{array}{l}\text { 5. Inter-linking } \\
\text { of working } \\
\text { and learning }\end{array}$ & $\begin{array}{l}\text { Participants learn by } \\
\text { performing real tasks } \\
\text { from practice. They are } \\
\text { supported by educational } \\
\text { interventions that are } \\
\text { attuned to the task and to } \\
\text { the individual learner, } \\
\text { inter-linking working and } \\
\text { learning }\end{array}$ & $\begin{array}{l}\text { Assignments are authentic, } \\
\text { in most cases ill- } \\
\text { structured and non- } \\
\text { routine } \\
\text { Supportive information is } \\
\text { to-the-point and timely } \\
\text { Coaching is provided at } \\
\text { critical times, to groups } \\
\text { or individuals }\end{array}$ & $\begin{array}{l}\text { Billett (2002); Griffiths and } \\
\text { Guile (2003); Kessels } \\
\text { (2001); Tynjälä (2008) }\end{array}$ \\
\hline $\begin{array}{l}\text { 6. Facilitating } \\
\text { reflection }\end{array}$ & $\begin{array}{l}\text { Participants learn by } \\
\text { reflection on tasks and } \\
\text { experiences as a person, } \\
\text { as a team and as an } \\
\text { organisation } \\
\text { Critical events in the } \\
\text { working activities are the } \\
\text { starting point for } \\
\text { reflection and learning }\end{array}$ & $\begin{array}{l}\text { Development of reflective } \\
\text { skills is facilitated } \\
\text { 'Lessons learned' are } \\
\text { formulated at critical } \\
\text { times } \\
\text { Peer feedback and/or group } \\
\text { counselling sessions are } \\
\text { facilitated }\end{array}$ & $\begin{array}{l}\text { Guile and Griffiths (2001); } \\
\text { Illeris (2002); Kolb } \\
\text { (1984); Schön (1987); } \\
\text { Tynjälä (2008) }\end{array}$ \\
\hline $\begin{array}{l}\text { 7. Enhancing } \\
\text { individual } \\
\text { talents }\end{array}$ & $\begin{array}{l}\text { Explicit attention is given } \\
\text { to participants' } \\
\text { personality, } \\
\text { characteristics, interests, } \\
\text { motivation and talents. } \\
\text { The development of a } \\
\text { professional identity is a } \\
\text { goal }\end{array}$ & $\begin{array}{l}\text { Assignments align with } \\
\text { personal interest and the } \\
\text { learners' motivation } \\
\text { Participants' characteristics } \\
\text { and personality are made } \\
\text { explicit }\end{array}$ & $\begin{array}{l}\text { Damasio (1994); Illeris } \\
\text { (2002); Meijers and } \\
\text { Wardekker (2001); } \\
\text { Pekrun and Linnenbrink- } \\
\text { Garcia (2012); Strauser } \\
\text { et al. (2008) }\end{array}$ \\
\hline $\begin{array}{l}\text { 8. Assessing for } \\
\text { learning }\end{array}$ & $\begin{array}{l}\text { Feedback and formative } \\
\text { assessment of individual } \\
\text { personal and professional } \\
\text { development are } \\
\text { provided at regular times } \\
\text { during the learning period }\end{array}$ & $\begin{array}{l}\text { Learning goals and } \\
\text { learning results emerge } \\
\text { from reflection on } \\
\text { experiences and } \\
\text { comparing oneself to the } \\
\text { professional profile of an } \\
\text { expert } \\
\text { Regular individual } \\
\text { coaching on the } \\
\text { progression of learning is } \\
\text { offered }\end{array}$ & $\begin{array}{l}\text { Boud (2007); Gibbs and } \\
\text { Simpson (2004); } \\
\text { Mentkowski et al. (2000); } \\
\text { Tynjälä et al. (2003); Van } \\
\text { Merriënboer and } \\
\text { Sluijsmans (2009) }\end{array}$ \\
\hline $\begin{array}{l}\text { 9. Enabling } \\
\text { organisation }\end{array}$ & $\begin{array}{l}\text { The organisational } \\
\text { structure and culture } \\
\text { supports the working } \\
\text { process, knowledge } \\
\text { creation and sharing at } \\
\text { every level (individual, } \\
\text { team, organisation, } \\
\text { society) }\end{array}$ & $\begin{array}{l}\text { Junior and senior } \\
\text { participants share the } \\
\text { physical working space } \\
\text { Knowledge products are } \\
\text { saved, documented and } \\
\text { utilised in further projects } \\
\text { or activities } \\
\text { Activities and procedures } \\
\text { allow for sharing of } \\
\text { knowledge and } \\
\text { experiences }\end{array}$ & $\begin{array}{l}\text { Nonaka and Takeuchi } \\
\text { (1995); Senge (1990) }\end{array}$ \\
\hline
\end{tabular}




\section{Stage III: evaluation}

The goal of this stage was to test both the pragmatic justification for the design principles and the completeness of the set of principles (McKenney and Reeves 2012). In line with Van den Akker's (2003) categorisation of curricula, the design principles and the corresponding design of the learning configuration can be seen as the intended curriculum, which is understood as the vision or basic philosophy underlying a curriculum. When evaluating the principles in practice, we can only work with the implemented curriculumthe way in which the curriculum is actually used in practice - and the attained curriculum, which is the curriculum as perceived or experienced by the participants.

Therefore we took the perspective of the participants and explored the questions of how, and to what extent, the initial design principles manifested themselves in practice. In addition, we were interested in effects of these manifestations on the participants and conditions under which these effects appeared. We also looked for possible new design principles that were perceived but not made explicit in the design framework. This resulted in a set of refined design principles. In summary, the relevant questions in this stage were:

- How and to what extent do the design principles manifest themselves in practice, as perceived by the participants of the learning configuration (students and faculty)?

- What are perceived features of the design principles, which effects of these features are reported and which conditions are mentioned under which these effects appeared?

- To what extent do new principles emerge?

Data were collected from iterations 4,5 and 6 during this stage.

\section{Method}

Because we were interested in participants' experiences, we chose a qualitative research method. Semi-structured interviews with students and staff were carried out in iterations 4, 5 and 6. The interviews were aimed at eliciting the experience of the participants, or the attained curriculum. In order to avoid any bias towards the implemented curriculum, the design principles and features that were explicitly implemented by the designers were not presented to the interviewees. This gave the interviews a very open character.

\section{Data collection}

In the fourth iteration, four students (out of 22) and five faculty (out of 12) were interviewed about how they experienced participating in the learning configuration and what they had learned. In iteration 5, four students (of 17) were interviewed in a similar way. The duration of the interviews was between $45 \mathrm{~min}$ and an hour.

At the end of iteration 6, nine students (out of 10) were interviewed as a group, because student interaction might result in increased elaboration and discussion (Frey and Fontana 1991). Topics included differences between this learning configuration and 'school', different ways of teaching and learning, the physical setting, and what was gained by participating in the HLC. Two researchers, one of whom was external to the HLC, carried out this interview. The duration was approximately $2 \mathrm{~h}$ including a short break.

All 11 faculty members were interviewed individually. They were expected (based on observations by the researcher) to speak more freely in an individual interview setting than in a group setting. They were asked to prepare for the interview by creating an image of the 
learning environment with themselves in it. This was the starting point for the interview. The focus was on how participants experienced working within this learning configuration and what they considered to be its strengths and weaknesses. At the end of these interviews, the faculty were asked to reflect on the nine initial design principles. The duration of these interviews varied from $1 \mathrm{~h}$ to $90 \mathrm{~min}$.

\section{Participant selection}

In order to maximise the range of information uncovered, interviewees were selected who represented the diversity of the group (Guba 1981). Students interviewed in iterations 4 and 5 came from both educational levels (MBO and $\mathrm{HBO}$ ) and from both technical and agricultural study programmes. Business and education faculty were represented in iteration 4. The four interviewed lecturers included representatives from both $\mathrm{MBO}$ and HBO levels and both technical and agricultural study programmes.

In iteration 6, all students (except for one) and faculty were interviewed. This way, all participants, faculty and students were given a voice from their own perspective (Brooker and Macdonald 1999). The educational consultants, project manager and secretary were also interviewed. Table 2 provides an overview of the interviewees in iterations 4-6.

\section{Data analysis}

Data were analysed in three steps, as is shown in the overview of methods used in the four stages of EDR (Fig. 2). First, all the interviews were recorded and transcribed. Second, the interviews were all coded according to the initial design principles (concept-driven coding, Gibbs 2007). Possible new principles were coded in vivo (open coding, Gibbs 2007). At the same time (within the codes for each principle), the various manifestations of a principle were coded as a feature of that principle via the method of constant comparison (Gibbs 2007). For instance, a feature of the principle 'fostering authenticity' appeared to be 'being seen as a company (and not as a school) by the outside world'. If participants mentioned an effect of the feature or a condition under which this effect appeared, this was coded as well. This resulted in lists of quotes for each distinct feature of the design principles.

Third, we determined for each feature its effects and conditions (as far as the data showed). Similar quotes were summarised into one description in order to reduce data. For

Table 2 Interviewees per iteration

\begin{tabular}{|c|c|c|}
\hline Iteration & Interviewees & Characteristics \\
\hline \multirow[t]{2}{*}{4} & $\begin{array}{l}4 \text { students } \\
\text { (individual) }\end{array}$ & $\begin{array}{l}\text { Students represented } 4 \text { different fields of study and two education levels } \\
(\mathrm{MBO} \text { and } \mathrm{HBO})\end{array}$ \\
\hline & $\begin{array}{l}5 \text { faculty } \\
\text { (individual) }\end{array}$ & $\begin{array}{l}\text { Faculty representing business (1) and education (4: } 3 \text { fields of study and two } \\
\text { educational levels) }\end{array}$ \\
\hline 5 & $\begin{array}{l}4 \text { students } \\
\text { (individual) }\end{array}$ & $\begin{array}{l}\text { Students represented } 4 \text { different fields of study and two education levels } \\
\text { (MBO and } \mathrm{HBO})\end{array}$ \\
\hline \multirow[t]{2}{*}{6} & $\begin{array}{l}9 \text { students } \\
\text { (group) }\end{array}$ & All students (save for one) were interviewed \\
\hline & $\begin{array}{l}11 \text { faculty } \\
\text { (individual) }\end{array}$ & Every faculty member was interviewed \\
\hline
\end{tabular}




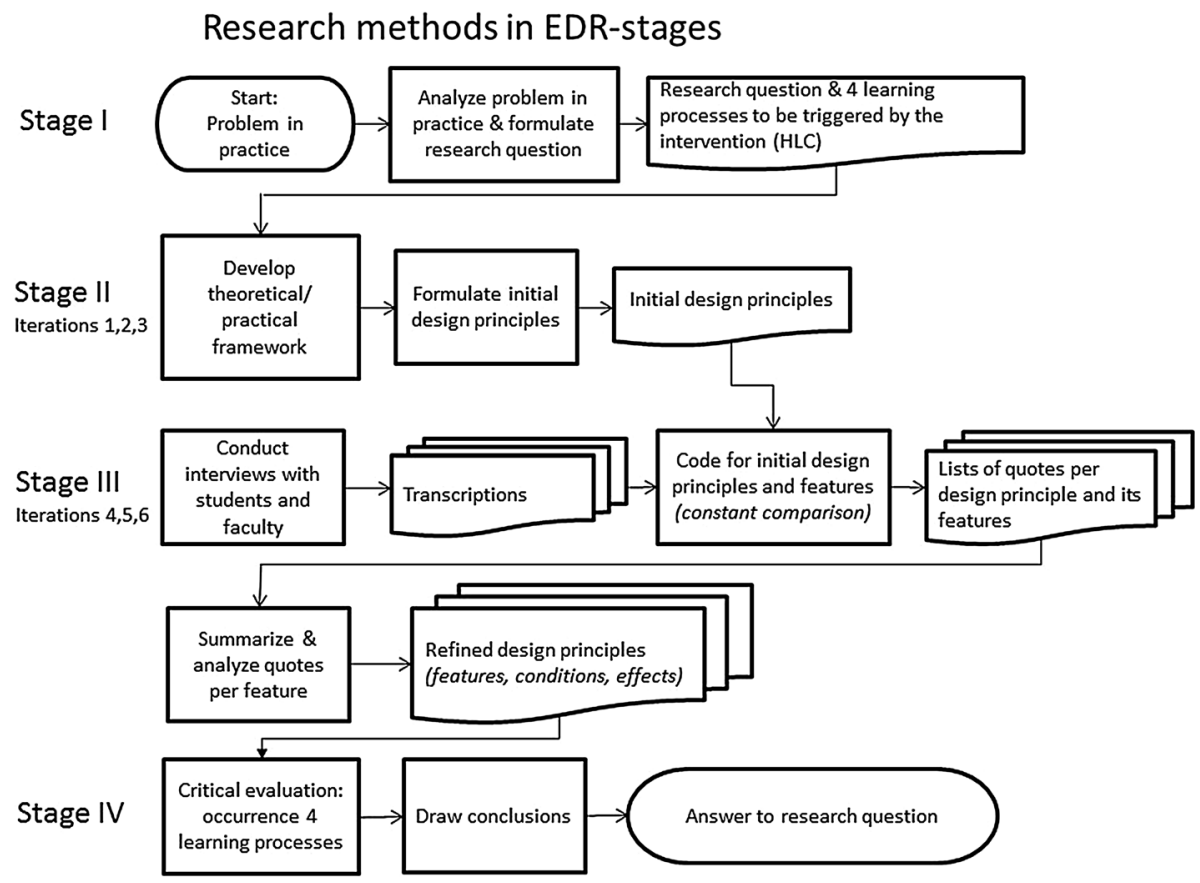

Fig. 2 Overview of methods used in EDR stages

instance, for the principle 'utilising diversity', a feature was summarised as 'explaining to others'. This was a summary of six similar quotes from students that concerned the need to explain their knowledge to others in their team, such as: "You have to make sure the whole group knows what it is about"; "I have to explain my expertise step by step"; "I could teach the others about building construction", and so on. Respondents sometimes mentioned an effect, such as "If you explain it, you understand it better yourself". The following condition was mentioned "... because we knew well that everyone had to input their knowledge into the project”.

\section{Validity and trustworthiness}

Several measures were taken in order to increase the trustworthiness of this study. The coding process was documented in ATLAS-ti. Memos were created for any decisions and dilemmas encountered during coding. A code book and research log were also created. The coding process and the analysis and summary of features were reviewed by another researcher who was not involved in this research. This rigour in coding and the check by a peer researcher (intersubjectivity) is likely to diminish the likelihood of researcher bias and enhance transparency or 'trackability' (Gravemeijer and Cobb 2006).

In order to paint as truthful a picture as possible (ecological validity), every participant's perspective was included in the data (Brooker and Macdonald 1999). In addition, every distinguished feature was included in the findings regardless of the number of respondents who brought it up. This was done because, in the words of Eisner (1991, p. 103), “... [e]very particular is also a sample of a larger class. In this sense, what has been learned 
about a particular can have relevance for the class to which it belongs. The theme embedded in the particular situation, extends beyond the situation itself". In a similar vein, Wals (1994, pp. 231-232) says: "Hence, what one learns about one student's or a small group of students' thinking [...] can raise one's consciousness of features that might be found among other students." Thus, the data are not a general consensus among participants but rather a collection of experiences.

The researcher was part of the learning configuration's project team. An advantage of being involved in the practice that is being researched is that the researcher can develop an understanding of and familiarity with the participants, their language and culture (Herr and Anderson 2005). Being familiar to the interviewees, however, could also diminish the validity of the interview data. Having participated in the learning configuration's design and implementation, it is possible for the researcher and the faculty to become biased in a positive way towards the learning configuration. (Herr and Anderson 2005). The researcher attempted to avoid this bias by asking open, non-suggestive questions in the interviews (Rubin and Rubin 2006), by always trying to focus on both negative and positive experiences of the participants, and by reflecting from time to time on what was being said. This 'learning attitude' by the researcher is likely to allow room for the respondents' agency, which would undo or at least combat researcher bias (Savin-Baden and Howell Major 2010). Quotes from three of the interviewees indicated such agency in the sense that they obtained new insights by reflecting on the learning configuration during the interview. In addition, the raw interview data were anonymised and treated confidentially. The fact that the researcher was not involved in assessing the students' learning outcomes probably enabled students to be honest and feel free to speak their mind.

\section{Findings}

In this section, we present the key findings. First, we describe the extent to which the design principles could be recognised in quotes by the students and faculty in the learning configuration. Next, we present the refined design principles as a set of tables that represent the features themselves, their effects and conditions. Last, we discuss new design principles and features that seem to emerge from the data.

\section{Design principles in practice}

The participants' quotes related to features of all nine design principles, though certain principles appeared more frequently than others. 'Creating a learning community' (19\% of 596 total quotes), 'inter-linking working and learning' (19\%) and 'fostering authenticity' $(18 \%)$ appeared most often in the interviews, followed by 'utilising diversity' and 'enabling organisation' (each $14 \%$ ). 'Assessing for learning' (7\%), 'facilitating reflection' (5\%), 'increasing ownership' (3\%) and 'enhancing individual talents' $(1 \%)$ were less prominent. Comments on 'enabling organisation' were mentioned almost exclusively by faculty.

\section{Design principles refined}

During the coding process, it became clear that the principles 'facilitating reflection', 'enhancing individual talents' and 'assessing for learning' seemed to overlap. Their features and the relevant quotes all seemed to relate to one another and to each of the three 
principles. After reconsidering the theoretical underpinnings of these initial design principles (Stage II, analysis and exploration) and the empirical findings, we came to the conclusion that the common denominator in the three principles was the concept of reflexivity. Reflexivity, as Thompson and Pascal (2012) argue, is premised on self-analysis, which they view as a key factor in critically reflective practice. In the light of this, we merged these three principles into a new principle, namely facilitating reflexivity. All quotes related to the new principle were pasted into one document and re-coded.

Almost all quotes relating to the design principle 'increasing ownership' referred to the culture of the learning configuration, fostering an increasing sense of responsibility or ownership in the students. Following Billett (2011), we concluded that learners who are participating in a community of professional workers need to be (or become) pro-active and agentic learners. Therefore 'increasing ownership' was regarded as a feature of the design principle 'creating a learning community'. The effect of these consolidations was a reduction from nine design principles to six.

The features of the six remaining design principles are presented in Tables 3, 4, 5, 6, 7, 8 , one table per principle. The features of each principle are presented in a random order. Relationships between features and differences in importance are not indicated or suggested. For each feature, the effects on the participants (students (S) and/or faculty (F)) and the conditions under which the effects appeared (if apparent in the data) are indicated. Where it was obvious that the respondents did not agree with each other, this is indicated by no consensus. If the participants mentioned that a certain feature needed improvement, this is indicated as well.

\section{Emerging design principles}

The goal of the evaluation stage in EDR is to underpin the set of initial design principles empirically by evaluating how they manifest themselves in practice. However, practice itself can reveal relevant aspects of the design that were not intended or made explicit by the designers. Some indications for new principles emerged from the data.

Many faculty members and some of the students discussed the relationships between the learning configuration and its surroundings. This relationship did not seem to be satisfactory. For instance, lecturers and managers within the participating education institutions

Table 3 Fostering authenticity: features, effects and conditions mentioned by students (S) and faculty (F)

\begin{tabular}{|c|c|c|}
\hline Features & Effects & Conditions \\
\hline Authentic assignment & Challenging, motivating (S) & Actively interested clients \\
\hline Professional culture & Professional behaviour $(\mathrm{S})$ & $\begin{array}{l}\text { Respecting and living up to rules } \\
\text { and values (should be improved) }\end{array}$ \\
\hline Being seen as a company & $\begin{array}{l}\text { Easy access to external experts (S) and } \\
\text { (potential) clients }(\mathrm{F})\end{array}$ & - \\
\hline $\begin{array}{l}\text { Senior participants from } \\
\text { education and business }\end{array}$ & $\begin{array}{l}\text { Feedback from both enhances quality of } \\
\text { work by students }(\mathrm{F})\end{array}$ & $\begin{array}{l}\text { Balanced participation from } \\
\text { education and business }\end{array}$ \\
\hline $\begin{array}{l}\text { Location in business } \\
\text { environment }\end{array}$ & $\begin{array}{l}\text { Professional behaviour, appreciation }(\mathrm{S}) \text {; } \\
\text { taken seriously by external relations }(\mathrm{F})\end{array}$ & Finances for the rent \\
\hline $\begin{array}{l}\text { Seniors and juniors as } \\
\text { colleagues }\end{array}$ & Taking each other more seriously $(\mathrm{S}, \mathrm{F})$ & - \\
\hline $\begin{array}{l}\text { Integrated school/work } \\
\text { culture }\end{array}$ & $\begin{array}{l}\text { Feels like a company }(\mathrm{S}, \mathrm{F}) \text {; feels like } \\
\text { school }(\mathrm{S}, \mathrm{F}) \text { - no consensus }\end{array}$ & - \\
\hline
\end{tabular}


Table 4 Creating a learning community: features, effects and conditions mentioned by students (S) and faculty $(\mathrm{F})$

\begin{tabular}{|c|c|c|}
\hline Features & Effects & Conditions \\
\hline $\begin{array}{l}\text { Learning from } \\
\text { and with } \\
\text { each other }\end{array}$ & Useful tips and ideas $(\mathrm{S}, \mathrm{F})$ & $\begin{array}{l}\text { Activities for information exchange } \\
\text { between teams; working in } \\
\text { Communities of Practice }(\mathrm{S}, \mathrm{F})\end{array}$ \\
\hline Ownership & Taking responsibility; showing initiative $(\mathrm{S})$ & $\begin{array}{l}\text { Making students responsible; clear } \\
\text { expectations; professional } \\
\text { environment; coaching }(\mathrm{F})\end{array}$ \\
\hline $\begin{array}{l}\text { Sense of } \\
\text { community }\end{array}$ & $\begin{array}{l}\text { Enjoying working and having fun at the same } \\
\text { time; being willing to help each other; } \\
\text { feeling at home }(\mathrm{S}) \text {; being yourself }(\mathrm{F})\end{array}$ & $\begin{array}{l}\text { Culture of respect; openness; genuine } \\
\text { interest in each other; equality; } \\
\text { knowing each other personally }\end{array}$ \\
\hline Learner equity & $\begin{array}{l}\text { Improved coaching of students and learning by } \\
\text { faculty }(\mathrm{F})\end{array}$ & $\begin{array}{l}\text { Congruent learning activities by faculty } \\
\text { and students, each at their own level } \\
\text { (could be improved) }\end{array}$ \\
\hline
\end{tabular}

Table 5 Utilising diversity: features, effects and conditions mentioned by students (S) and faculty (F)

\begin{tabular}{|c|c|c|}
\hline Features & Effects & Conditions \\
\hline $\begin{array}{l}\text { Working with people from } \\
\text { different disciplines and } \\
\text { education levels }\end{array}$ & $\begin{array}{l}\text { Learned a lot from other disciplines; for } \\
\text { different education levels collaboration } \\
\text { (S) and coaching (F) was sometimes } \\
\text { difficult }\end{array}$ & Good coaches \\
\hline Learning from each other & Motivation to learn; getting new ideas (S) & - \\
\hline Using different points of view & $\begin{array}{l}\text { More people }=\text { more ideas }=\text { better results } \\
(\mathrm{S}) \text {; better learning }(\mathrm{F})\end{array}$ & $\begin{array}{l}\text { Balanced diversity in } \\
\text { characteristics of team } \\
\text { members }\end{array}$ \\
\hline Collaboration & $\begin{array}{l}\text { Combining knowledge requires collaboration; } \\
\text { dividing tasks is not enough }(\mathrm{S}) \text {; } \\
\text { collaboration reinforces learning by } \\
\text { combining knowledge }(\mathrm{F})\end{array}$ & - \\
\hline $\begin{array}{l}\text { Feedback from different } \\
\text { people }\end{array}$ & $\begin{array}{l}\text { Stimulates reflection and learning about } \\
\text { oneself }(\mathrm{S}, \mathrm{F})\end{array}$ & $\begin{array}{l}\text { Feedback from people } \\
\text { with different } \\
\text { backgrounds and views }\end{array}$ \\
\hline $\begin{array}{l}\text { Meeting new and interesting } \\
\text { people }\end{array}$ & $\begin{array}{l}\text { Inspiration by meeting new colleagues from } \\
\text { other fields }(\mathrm{F})\end{array}$ & - \\
\hline Using each other's strengths & $\begin{array}{l}\text { Everyone is challenged to contribute and feels } \\
\text { respected and valued for their input }(\mathrm{S}, \mathrm{F})\end{array}$ & $\begin{array}{l}\text { Everyone's input is } \\
\text { needed for the task }\end{array}$ \\
\hline Explaining to others & $\begin{array}{l}\text { Understanding of task improves; becoming } \\
\text { more helpful, more assertive }(\mathrm{S})\end{array}$ & $\begin{array}{l}\text { Everyone's input is } \\
\text { needed for the task }\end{array}$ \\
\hline
\end{tabular}

were sometimes not sufficiently informed about or committed to the learning configuration. For example, a lecturer commented: "There is not a real connection with the partnerschools. They all say it is fantastic what we are doing, but they don't do anything with it; they merely watch it from the sideline." This suggests that the participants experienced a boundary between the HLC and its surroundings. This boundary could be related to the process of hybridisation (Akkerman and Bakker 2011), in the sense that ingredients of established practices (i.e. school and workplace) are combined, resulting in a new practice (the HLC) with its own boundary. 
Table 6 Inter-linking of working and learning: features, effects and conditions mentioned by students (S) and faculty (F)

\begin{tabular}{|c|c|c|}
\hline Features & Effects & Conditions \\
\hline $\begin{array}{l}\text { New ways of } \\
\text { learning }\end{array}$ & $\begin{array}{l}\text { Learning by doing and discussing }(\mathrm{S}) \text {; } \\
\text { learning by collaboration }(\mathrm{F})\end{array}$ & - \\
\hline $\begin{array}{l}\text { Learning by } \\
\text { example }\end{array}$ & Learning by watching others work (S, F) & Working in the same room \\
\hline $\begin{array}{l}\text { Balance } \\
\text { structure- } \\
\text { letting go }\end{array}$ & $\begin{array}{l}\text { Too much structure }(\mathrm{S}, \mathrm{F}) \text {; not enough } \\
\text { structure }(\mathrm{S}, \mathrm{F}) \text { - no consensus }\end{array}$ & - \\
\hline $\begin{array}{l}\text { Using a method } \\
\text { for working in } \\
\text { projects }\end{array}$ & Efficient learning by students $(\mathrm{F})$ & $\begin{array}{l}\text { Focus on problem first; reflect on } \\
\text { milestones }\end{array}$ \\
\hline $\begin{array}{l}\text { Using external } \\
\text { expertise }\end{array}$ & $\begin{array}{l}\text { Verification of information; generating new } \\
\text { ideas, inspiration (S) }\end{array}$ & $\begin{array}{l}\text { Coaching and stimulating students 'to } \\
\text { go outside' }\end{array}$ \\
\hline $\begin{array}{l}\text { Balanced focus } \\
\text { of learning }\end{array}$ & $\begin{array}{l}\text { Right balance between focus on task, process, } \\
\text { person and knowledge (F)—no consensus } \\
\text { about the right balance }\end{array}$ & - \\
\hline $\begin{array}{l}\text { Balance } \\
\text { working/ } \\
\text { learning } \\
\text { activities }\end{array}$ & $\begin{array}{l}\text { Learning activities support working activities } \\
\text { (should not disrupt each other) (S, F) }\end{array}$ & $\begin{array}{l}\text { Supportive information is timely, to- } \\
\text { the-point, tailored to participants }\end{array}$ \\
\hline $\begin{array}{l}\text { Adaptive } \\
\text { interventions }\end{array}$ & $\begin{array}{l}\text { Interventions when needed, not too ad hoc (S, } \\
\text { F) }\end{array}$ & $\begin{array}{l}\text { Underlying educational concepts and } \\
\text { instruments }\end{array}$ \\
\hline $\begin{array}{l}\text { Increasingly } \\
\text { complex tasks }\end{array}$ & $\begin{array}{l}\text { First learning 'how it works here' during } \\
\text { easier tasks works well (S) }\end{array}$ & $\begin{array}{l}\text { Efficiency; saving enough time for the } \\
\text { most complex assignment (F not sure } \\
\text { how to accomplish this) }\end{array}$ \\
\hline $\begin{array}{l}\text { Guiding } \\
\text { students' } \\
\text { learning }\end{array}$ & Very helpful (S) & $\begin{array}{l}\text { Different senior roles: coach, client's } \\
\text { representative, expert }\end{array}$ \\
\hline
\end{tabular}

Table 7 Facilitating reflexivity: features, effects and conditions mentioned by students (S) and faculty (F)

\begin{tabular}{lll}
\hline Features & Effects & Conditions \\
\hline $\begin{array}{c}\text { Assessment for } \\
\text { learning }\end{array}$ & Thinking about what is learned (S) & $\begin{array}{c}\text { Setting goals and reflecting on } \\
\text { learning with coach }\end{array}$ \\
$\begin{array}{c}\text { Focus on } \\
\text { person }\end{array}$ & $\begin{array}{c}\text { Understanding behaviour of oneself and others; } \\
\text { consciously making more future-oriented choices; } \\
\text { growing as a whole person (S) }\end{array}$ & $\begin{array}{c}\text { Facilitating individual personal } \\
\text { and professional development }\end{array}$ \\
$\begin{array}{c}\text { Reflection on } \\
\text { action }\end{array}$ & $\begin{array}{c}\text { Taking responsibility for learning; wanting to } \\
\text { improve and live up to expectations (S) }\end{array}$ & $\begin{array}{c}\text { Tools for and dialogue about } \\
\text { feedback }\end{array}$ \\
$\begin{array}{c}\text { Reflection } \text { in } \\
\text { action }\end{array}$ & $\begin{array}{c}\text { Continually thinking about what we do and why (S) } \\
\text { Feedback from practice; } \\
\text { immediate adjustment and }\end{array}$ \\
$\begin{array}{c}\text { Connectivity } \\
\text { school }\end{array}$ & $\begin{array}{c}\text { Learning outcomes compatible with study } \\
\text { programme (S) }\end{array}$ & $\begin{array}{c}\text { improvement } \\
\text { plear communication with } \\
\text { school; relevant assignments }\end{array}$ \\
\hline
\end{tabular}


Table 8 Enabling organisation: features, effects and conditions mentioned by students (S) and faculty (F)

\begin{tabular}{|c|c|c|}
\hline Features & Effects & Conditions \\
\hline $\begin{array}{l}\text { Facilitating } \\
\text { working and } \\
\text { learning }\end{array}$ & Being creative as well as organised $(\mathrm{F})$ & $\begin{array}{l}\text { Small community; 'face-to-face time', } \\
\text { flexible organisation structure }\end{array}$ \\
\hline $\begin{array}{l}\text { Sharing } \\
\text { physical } \\
\text { space }\end{array}$ & $\begin{array}{l}\text { Easy contact students and faculty; knowing } \\
\text { who has which expertise; learning by } \\
\text { example (S, F) }\end{array}$ & $\begin{array}{l}\text { Students and faculty working in the } \\
\text { same room }\end{array}$ \\
\hline $\begin{array}{l}\text { Connectivity } \\
\text { stakeholders }\end{array}$ & $\begin{array}{l}\text { Participating institutions involved and } \\
\text { committed (also financially) (F) }\end{array}$ & $\begin{array}{l}\text { Shared vision and concepts; } \\
\text { communication tailored to different } \\
\text { stakeholders (needs improvement) }\end{array}$ \\
\hline $\begin{array}{l}\text { Learning } \\
\text { organisation }\end{array}$ & On-going development and innovation (F) & $\begin{array}{l}\text { Research, reflection, monitoring and } \\
\text { evaluation (not: routine, } \\
\text { specialisation, differentiation of } \\
\text { tasks) }\end{array}$ \\
\hline Explicit culture & Coaching on cultural aspects $(\mathrm{F})$ & $\begin{array}{l}\text { Making culture explicit when } \\
\text { introducing new participants }\end{array}$ \\
\hline
\end{tabular}

Hence a possible new principle emerged which calls for the learning configuration to be in tune with its surroundings, bridging the boundary with its partner institutions and other stakeholders, such as (potential) clients. This design principle could be called 'enabling ecology',

Another issue mentioned by several faculty members involved the participants in the learning configuration and their incentive to be involved. For students, it did not seem to matter how well they had been performing in their own study programme so far; some 'weak' students appeared to blossom in this learning environment. The performance requirements, however, did seem to be a motivating factor. Some of the students for whom no particular learning outcomes were required by their own study programme did not seem to be as motivated as either the students who did have requirements from their own programme or those who joined the study with their own set of learning outcomes. One faculty member from industry lost some of his motivation when he could not meet his own goal: "I notice a de-motivation because I am not going to reach my goal here, which is to apply the Value in the Valley concept to a business environment." This issue can be viewed as a feature of the new principle of 'enabling ecology': balanced performance requirements. The relevant balance would have to be struck both within and outside the learning configuration.

A third issue mentioned by several faculty members was the need to be creative and innovative and to remain that way. This was viewed as important because a knowledge worker requires a learning and working environment that is not stagnant. The following two threats to creativity and innovativeness were mentioned: task differentiation and the routine performance of tasks. Participants said: "After several iterations, we know how to do the workshop on innovation." This call for innovativeness seems paradoxical in the following way. In order to develop and improve the learning configuration, one must keep what works well, but 'what works well' should not become either too routine or the task of a single person. In order to address these issues, an extra feature of 'enabling organisation' might be introduced, namely, ongoing innovation. 


\section{Stage IV: drawing conclusions}

The findings presented in the previous section indicate how the initial design principles manifested themselves in practice as perceived by the participants. Three of the initial design principles ('facilitating reflection' 'enhancing individual talents' and 'assessing for learning') were merged into a new one: 'facilitating reflexivity'. The remaining set of six design principles was refined with features, effects and conditions. The new principle 'enabling ecology' was added to the initial set of principles. A feature of this principle is 'balanced performance requirements'. Also a new feature for the principle 'enabling organisation' emerged: ongoing innovation. Table 9 shows the initial as well as the refined design principles and their description.

With the knowledge of how the initial design principles were enacted in practice, we are now able to generate an answer to the main research question: Which set of principles can underpin the design of a hybrid learning configuration for educating the knowledge worker? We operationalised the research question (EDR stage I) by defining four desirable outcomes, namely, that the learning processes that should be evoked by the HLC: selfdirected learning, authentic learning, the development of a professional identity, and creating knowledge collaboratively across boundaries. In doing so, we connect the empirical data with the intentions of the design.

Table 9 Initial and refined design principles

\begin{tabular}{|c|c|c|}
\hline $\begin{array}{l}\text { Initial design } \\
\text { principles }\end{array}$ & $\begin{array}{l}\text { Refined design } \\
\text { principles }\end{array}$ & Description \\
\hline $\begin{array}{l}\text { 1. Fostering } \\
\text { authenticity }\end{array}$ & $\begin{array}{l}\text { 1. Fostering } \\
\text { authenticity }\end{array}$ & $\begin{array}{l}\text { Working/learning environment (context, tasks, activities, } \\
\text { roles, and communication) reflects working practice, a } \\
\text { professional working culture and organisation }\end{array}$ \\
\hline $\begin{array}{l}\text { 2. Creating a learning } \\
\text { community }\end{array}$ & $\begin{array}{l}\text { 2. Creating a learning } \\
\text { community }\end{array}$ & $\begin{array}{l}\text { Community: every member should experience a sense of } \\
\text { belonging to the community }\end{array}$ \\
\hline $\begin{array}{l}\text { 3. Increasing } \\
\text { ownership }\end{array}$ & & $\begin{array}{l}\text { Learner equity: every member of the community is a } \\
\text { learner, each at his/her level }\end{array}$ \\
\hline 4. Utilising diversity & 3. Utilising diversity & $\begin{array}{l}\text { Diversity is built-in, valued and utilised both at team and } \\
\text { organizational levels and in internal and external } \\
\text { networks }\end{array}$ \\
\hline $\begin{array}{l}\text { 5. Inter-linking of } \\
\text { working and } \\
\text { learning }\end{array}$ & $\begin{array}{l}\text { 4. Inter-linking of } \\
\text { working and } \\
\text { learning }\end{array}$ & $\begin{array}{l}\text { Participants learn by performing real life tasks supported } \\
\text { by educational interventions that are attuned to the task } \\
\text { and to the individual learner, inter-linking working and } \\
\text { learning }\end{array}$ \\
\hline $\begin{array}{l}\text { 6. Facilitating } \\
\text { reflection }\end{array}$ & $\begin{array}{l}\text { 5. Facilitating } \\
\text { reflexivity }\end{array}$ & $\begin{array}{l}\text { Participants learn by reflection on their tasks and } \\
\text { experiences as a person, team and organisation }\end{array}$ \\
\hline $\begin{array}{l}\text { 7. Enhancing } \\
\text { individual talents }\end{array}$ & & $\begin{array}{l}\text { Critical events in the working activities are the starting } \\
\text { point for reflection and learning }\end{array}$ \\
\hline \multicolumn{3}{|l|}{$\begin{array}{l}\text { 8. Assessing for } \\
\text { learning }\end{array}$} \\
\hline \multirow[t]{2}{*}{$\begin{array}{l}\text { 9. Enabling } \\
\text { organisation }\end{array}$} & $\begin{array}{l}\text { 6. Enabling } \\
\text { organisation }\end{array}$ & $\begin{array}{l}\text { The organisational structure and culture supports the } \\
\text { working process, knowledge creation and sharing at } \\
\text { every level (individual, team, organisation, society) }\end{array}$ \\
\hline & 7. Enabling ecology & $\begin{array}{l}\text { The learning configuration is attuned to its surroundings, } \\
\text { which includes partner organisations and other } \\
\text { stakeholders }\end{array}$ \\
\hline
\end{tabular}


In order to answer the research question, we critically evaluated the features of the refined design principles (Tables 3, 4, 5, 6, 7, 8) for indications of occurrences of these learning processes, and we provide exemplary interview quotes from which these features were drawn. The relevant design principles are referred to in italics. First, we investigate to what extent 'self-directed learning' seemed to be realised. Second, we address 'authentic learning' and discuss 'the development of a professional identity'. Next, we discuss 'creating new knowledge collaboratively across boundaries'. Last, we draw conclusions with respect to the main research question.

\section{Self-directed learning}

Self-directed learning is defined here as pro-active or autonomous learning (Candy 1991; Knowles 1975). It can be described as a cyclical process consisting of five stages: diagnosing learning needs, goal setting, planning activities, monitoring progress and evaluating the extent to which a learning goal has been attained (Cremers et al. 2014).

Some of these stages were apparent from the data. The students set their learning goals, reflected on their progress and evaluated what they had learned. This was facilitated by coaching, feedback from faculty and peers and a procedure for personal professional development (facilitating reflexivity). A student's comment on coaching was: "If someone tells you that you are good at something you want to keep being good at it. And you want to work on things you're not good at."

In general, students were not pro-active learners when they started. Over the course of each iteration, the students gradually began to take more responsibility for their working and learning (creating a learning community). "If you want to achieve something here, you have to take action" was a relevant comment by one of the students. A lecturer stated: "Not everyone, but most of the students start taking initiative once they discover that it is up to them to make it work here."

The principle creating a learning community seemed to have the effect of the students feeling at home and "being themselves", which enhanced their motivation for working and learning pro-actively within the learning configuration. It is also plausible that reflection was enhanced by a safe atmosphere. Faculty mentioned "being genuinely interested in each other", "knowing each other" and "taking each other seriously" as important conditions.

The faculty did not agree about how much the students should be guided or left to their own devices (inter-linking working and learning). Some argued that most is learnt when things go wrong, whereas others were striving for a balance between guidance and selfdirection in order to achieve an efficient learning process. They did agree that providing clear expectations and being a coach rather than an instructor are important success factors for self-directed learning. Faculty stressed the importance of individual coaching and the need to make the procedure of personal professional development (assessment for learning) more transparent and explicit.

It follows that the students' learning can be characterised as self-directed to a modest extent.

\section{Authentic learning}

The data suggest that authentic learning occurred in several ways. First, working on assignments from real clients motivated the students to work on the task (fostering authenticity). As a student put it: "It is really nice to know that someone will actually use the 
results." Students actively looked for information within and outside the learning configuration (inter-linking working and learning). One student said about this external focus: "You have to be more social here, you have to ask questions to people you don't know." According to one lecturer, this was facilitated "because the students are taken seriously by the client, by us and because Value in the Valley is seen as a company by the outside world" (fostering authenticity).

Students also learned from observing faculty at work (inter-linking working and learning, enabling organisation). They mentioned the following in their interviews: watching faculty members guide the student teams, witnessing a presentation or a telephone call, and attending a workshop from an expert. It follows that a certain kind of master-apprentice learning occurred. The faculty, however, did not work on the same projects as the students. They did not model the specific task for the students but were professional role models in a more general way. One student mentioned in the interview that he would have liked to collaborate with the faculty because "... that way, we would really have become colleagues". Another student was satisfied that faculty members from business supported students in their project (fostering authenticity): "Here people from practice think with us about our project; we get tips from business people."

The faculty did not agree on how best to balance the learning focus between knowledge, personal development, tasks and working procedures, and communication (inter-linking working and learning).

\section{Developing a professional identity}

Three aspects of students' development of a professional identity were apparent from the data. First, several students reported that they now know how a company works, even though most of them recognised that the learning configuration was not a real company in every way (fostering authenticity). They also started to behave in a more professional way by, for instance, "talking more decently", as one student put it, "dressing properly for meetings with clients", "answering the telephone and receiving guests in a professional way" and "communicating about and keeping appointments".

Second, students mentioned that they got to know themselves and others better, and they indicated that this made them both understand others better and react to them differently (facilitating reflexivity). Reflecting on what they learned (or obviously had not learned yet), seemed to make the students think more consciously about their future. For instance, they talked about what kind of role they would or would not like to play (e.g. project manager) in their future job, whether they would continue studying or start working after they finished their studies, and in which field they would like to work. Many students found 'sustainable development' to be a very broad and interesting field, while others said that they were firmly committed to their choice for a career in their original field of study. These comments show that most students seemed to have developed, to some extent, their identity as a person in relation to their studies or future career.

\section{Creating knowledge collaboratively, across boundaries}

An indication that new knowledge was created by collaborating in an interdisciplinary way (utilising diversity) was found in students' comments such as "We needed each other's knowledge to achieve a result" and "Here the project is more together, not divided into separate parts that you throw together in the end; you have to discuss with each other constantly". The interdisciplinarity of the teams (provided that each discipline was needed 
for the task to be carried out) seemed to enhance or trigger the following processes as well: a motivation to learn ("If others in my team can make telephone calls with clients, I should be able to do that as well"), getting to know oneself better ("I get feedback from people from different backgrounds who see things differently") and becoming more assertive. One lecturer stated: "Students become more assertive, because each student has something to contribute from his own background, so they are challenged to bring forward their own point of view." Faculty reported that, in some cases, intensive coaching was required to achieve empowerment and to prevent a downward spiral of conflict resulting in negative behaviour in the student teams. Therefore, guiding students' learning (inter-linked working and learning) seems to be an important condition for creating knowledge by multidisciplinary and 'multi-level' collaboration.

\section{Conclusions}

In summary, the principles 'fostering authenticity', 'inter-linking working and learning' and 'facilitating reflexivity' seemed to enhance authentic, self-directed learning and the development of a professional identity. The collaborative creation of knowledge across the boundaries of disciplines was reflected strongly in the principle 'utilising diversity'.

The data suggest a strong interconnection between the design principles. For instance, the principle of 'utilising diversity' appeared to enhance reflection and the motivation to learn. This, in turn, seemed to enhance the inter-linked working and learning that was needed in order to achieve knowledge creation, which occurred via interdisciplinary and multi-level collaboration. The principles 'creating a learning community' and 'enabling organisation' and the new principle 'enabling ecology' can be viewed as providing the necessary context for the other principles to be effective.

Thus, it seems justified to conclude that this set of design principles can indeed be thought to underpin the design of a HLC for educating the knowledge worker.

\section{Discussion and further research}

Ideally, in EDR, the practical goals and research questions are set at the beginning of the project by the researcher in collaboration with the practitioners. After this stage, a set of initial design principles is developed and implemented. These principles are then evaluated and refined after every iteration. In this case, however, the project began with general theoretical perspectives and the 'craft wisdom' of the designers. During the first iterations of design and implementation, the underlying assumptions and theories gradually became more explicit, which resulted in a set of initial design principles.

Iterations 4, 5 and 6 were based on these design principles and were evaluated. Because there was not much time between the iterations, the results of this evaluation were not directly put into practice in the next iteration. In addition, conclusions about the workings of the principles in practice were not drawn until after the end of the project. However, because the changes from one iteration to the next were minor and because every design principle was enacted in every iteration, we believe that we were justified in using the evaluation results of three consecutive iterations to reach our conclusions.

In this study, we explored how participants in a learning configuration experienced the manifestations of educational design principles in practice. It is possible that participants did not recognise all manifestations of the underlying design. For instance, few students 
commented on the design principle 'enabling organisation', possibly because they did not have a good idea of what an organisation entails. Also, lecturers might have different conceptions of how a design principle is or should be put into operation within the learning configuration.

In addition to giving a voice to the perspectives of the different participants (students and faculty), a 'member check' (Guba 1981) could have increased ecological validity and demonstrated whether the conclusions drawn were credible or 'ring true' to those who provided the data.

Another issue to take into account is the interdependence and coherence of the design principles. As indicated in our conclusion, the data revealed relations between the design principles. This implies that conclusions drawn about individual design principles always need to be considered in relation to the other principles. This interdependence also became apparent because certain features seemed to be related to more than one design principle. For instance, a feature of 'enabling organisation' was 'sharing physical space'. Although this feature can be seen as an organizational issue, it can also be viewed from the perspective of 'creating a learning community' because working together in one room could be expected to enhance a sense of community. Thus we conclude that, in line with Sandoval (2014), features of a learning environment can be inspired by multiple design principles. For the sake of reducing complexity, we chose to attribute each feature to the design principle that seemed to be most directly linked to it.

Two kinds of overall outcomes often measured in EDR are learning results and the usability of the intervention as a whole. Although these overall outcomes were not measured systematically in this study, other studies (e.g. Cremers and Hekman 2010) suggest that the students' learning results were in line with the intended learning outcomes and that both students and faculty enjoyed working and learning at the HLC. Interview data from this study seem to confirm this. Students seem to value the combination of "working seriously" within an informal atmosphere. Faculty often commented that the HLC offered a pleasant working environment and many opportunities for learning and developing themselves further as educators.

This study provides a set of design principles that, in this particular setting, appear to enhance authentic, self-directed learning as well as the development of a professional identity and the collaborative creation of knowledge across boundaries of disciplines, professions and perspectives. The set of design principles was presented here together with related features, effects and conditions. The features exemplify how the design principles can be applied, which enables other designers to utilise the principles in accordance with their own situation. In this way, the set of design principles can facilitate collaborative knowledge building for a wide range of communities that design and explore HLCs.

It follows that a logical direction for further research would be to monitor and test the utilisation of the design principles in other contexts with different features (Andriessen 2007; Kali 2006). In addition, further research could be aimed at revealing the underlying mechanisms that explain why a certain feature or intervention produces a certain effect or outcome (Denyer et al. 2008). This additional design knowledge would extend and deepen our understanding of how to design HLCs for the knowledge worker.

Acknowledgments The authors wish to thank the faculty and students of Value in the Valley for their valuable and inspiring contributions to this research project.

Open Access This article is distributed under the terms of the Creative Commons Attribution 4.0 International License (http://creativecommons.org/licenses/by/4.0/), which permits unrestricted use, distribution, and reproduction in any medium, provided you give appropriate credit to the original author(s) and the source, provide a link to the Creative Commons license, and indicate if changes were made. 


\section{References}

Akkerman, S. F., \& Bakker, A. (2011). Boundary crossing and boundary objects. Review of Educational Research, 81(2), 132-169.

Andriessen, D. (2007). Designing and testing an OD intervention. The Journal of Applied Behavioral Science, 43(1), 89-107.

Antonides, E. H., \& Hoetink, F. (2005). Projectplan value in the Valley, energie om te leren. Groningen: Alfa-college.

Billett, S. (1996). Situated learning: Bridging sociocultural and cognitive theorising. Learning and Instruction, 6(3), 263-280.

Billett, S. (2002). Toward a workplace pedagogy: Guidance, participation, and engagement. Adult Education Quarterly, 53(1), 27-43.

Billett, S. (2004). Learning through work: Workplace participatory practices. In H. Rainbird, A. Fuller, \& A. Munro (Eds.), Workplace learning in context (pp. 109-125). London: Routledge.

Billett, S. (2011). Integrating experiences in workplace and university settings: A conceptual perspective. In S. Billett \& A. Henderson (Eds.), Developing learning professional (pp. 21-40). London: Springer.

Billet, S., \& Somerville, M. (2004). Transformations at work: Identity and learning. Studies in Continuing Education, 26(2), 309-326.

Boud, D. (2007). Reframing assessment as if learning were important. In D. Boud \& N. Falchikov (Eds.), Rethinking assessment in higher education: Learning for the longer term (pp. 14-25). London: Routledge.

Bromme, R., \& Tillema, H. (1995). Fusing experience and theory: The structure of professional knowledge. Learning and Instruction, 5(4), 261-267.

Bronkhorst, L. H., Meijer, P. C., Koster, B., Akkerman, S. F., \& Vermunt, J. D. (2013). Consequential research designs in research on teacher education. Teaching and Teacher Education, 33, 90-99.

Brooker, R., \& Macdonald, D. (1999). Did we hear you?: Issues of student voice in a curriculum innovation. Journal of Curriculum Studies, 31(1), 83-97.

Brown, A. L., \& Campione, J. C. (1996). Psychological theory and the design of innovative learning environments: On procedures, principles, and systems. In L. Schauble \& R. Glaser (Eds.), Innovations in learning: New environments for education (pp. 289-325). Mahwah, NJ: Erlbaum.

Brown, J. S., Collins, A., \& Duguid, P. (1989). Situated cognition and the culture of learning. Educational Researcher, 18(1), 32-42.

Candy, P. C. (1991). Self-direction for lifelong learning: A comprehensive guide to theory and practice. San Francisco: Jossey-Bass.

Cremers, P. H. M., \& Hekman, E. G. A. (2010). Value in the Valley, evaluatie van het leerarrangement. Groningen: Value in the Valley.

Cremers, P. H. M., Wals, A. E. J., Wesselink, R., Nieveen, N., \& Mulder, M. (2014). Self-directed lifelong learning in hybrid learning configurations. International Journal of Lifelong Education, 33(2), 207-232.

Damasio, A. R. (1994). Descartes' error: Emotion, rationality and the human brain. New York: Putnam.

De Bruijn, E., \& Leeman, Y. (2010). Authentic and self-directed learning in vocational education: Challenges to vocational educators. Teaching and Teacher Education, 27(4), 694-702.

De Putter-Smits, L. G. A., Taconis, R., \& Jochems, W. M. G. (2013). Mapping context-based learning environments: The construction of an instrument. Learning Environments Research, 16(3), 437-462.

Denyer, D., Tranfield, D., \& Van Aken, J. E. (2008). Developing design propositions through research synthesis. Organization Studies, 29(3), 393-413.

Eisner, E. W. (1991). The enlightened eye: Qualitative inquiry and the enhancement of educational practice. New York: Macmillan Publishing.

Engeström, Y. (1999). Innovative learning in work teams: Analyzing cycles of knowledge creation in practice. In Y. Engeström, R. Miettinen, \& R. Punamaki (Eds.), Perspectives on activity theory (pp. 377-404). Cambridge: Cambridge University Press.

Eteläpelto, A., Vähäsantanen, K., Hökkä, P., \& Paloniemi, S. (2013). What is agency? Conceptualizing professional agency at work. Educational Research Review, 10, 45-65.

Frey, J. H., \& Fontana, A. (1991). The group interview in social research. The Social Science Journal, 28(2), $175-187$.

Gibbons, M., Limoges, C., \& Nowotny, H. (1997). The new production of knowledge: The dynamics of science and research in contemporary societies. London: Sage Publications.

Gibbs, G. (2007). Analyzing qualitative data. London: Sage Publications.

Gibbs, G., \& Simpson, C. (2004). Conditions under which assessment supports students' learning. International Learning and Teaching in Higher Education, 16(1), 3-31. 
Gravemeijer, K., \& Cobb, P. (2006). Design research from a learning design perspective. In J. Van den Akker, K. Gravemeijer, S. McKenney, \& N. Nieveen (Eds.), Educational design research (pp. 17-51). New York: Routledge.

Griffiths, T., \& Guile, D. (2003). A connective model of learning: The implications for work process knowledge. European Educational Research Journal, 2(1), 56-73.

Guba, E. G. (1981). Criteria for assessing the trustworthiness of naturalistic inquiries. Educational Technology Research and Development, 29(2), 75-91.

Guile, D., \& Griffiths, T. (2001). Learning through work experience. Journal of Education and Work, 14(1), $113-131$.

Hargreaves, A. (2003). Teaching in the knowledge society: Education in the age of insecurity. New York: Teachers College Press.

Herr, K., \& Anderson, G. L. (2005). The action research dissertation: A guide for students and faculty. Thousand Oaks, CA: Sage Publications.

Herrington, J., \& Oliver, R. (2000). An instructional design framework for authentic learning environments. Educational Technology Research and Development, 48(3), 23-48.

Huisman, J., De Bruijn, E., Baartman, L., Zitter, I., \& Aalsma, E. (2010). Leren in hybride leeromgevingen in het beroepsonderwijs. Praktijkverkenning, theoretische verdieping. Utrecht: Expertisecentrum Beroepsonderwijs.

Illeris, K. (2002). The three dimensions of learning: Contemporary learning theory in the tension field between the cognitive, the emotional and the social. Copenhagen: Roskilde University Press.

Kali, Y. (2006). Collaborative knowledge building using the design principles database. International Journal of Computer-Supported Collaborative Learning, 1(2), 187-201.

Kali, Y., Levin-Peled, R., \& Dori, Y. J. (2009). The role of design-principles in designing courses that promote collaborative learning in higher-education. Computers in Human Behavior, 25(5), 1067-1078.

Kessels, J. W. M. (2001). Learning in organisations: A corporate curriculum for the knowledge economy. Futures, 33(6), 497-506.

Knowles, M. S. (1975). Self-directed learning: A guide for learners and teachers. Chicago: Follett.

Kolb, D. A. (1984). Experiential learning: Experience as the source of learning and development. Englewood Cliffs, NJ: Prentice-Hall.

Könings, K. D., Brand-Gruwel, S., \& van Merriënboer, J. J. G. (2007). Teachers' perspectives on innovations: Implications for educational design. Teaching and Teacher Education, 23(6), 985-997.

Lakkala, M., Ilomäki, L., Paavola, S., Kosonen, K., \& Muukonen, H. (2012). Using trialogical design principles to asssess pedagogcial practices in two higher education courses. In A. Moen, A. I. Morch, \& S. Paavola (Eds.), Collaborative knowledge creation: Practices, tools, concepts (pp. 141-162). Rotterdam: Sense Publishers.

Lave, J., \& Wenger, E. (1991). Situated learning: Legitimate peripheral participation. Cambridge: Cambridge University Press.

McKenney, S., \& Reeves, T. C. (2012). Conducting educational design research. Oxford: Routledge.

McKenney, S., Nieveen, N., \& Van den Akker, J. (2006). Design research from a curriculum perspective. In J. Van den Akker, K. Gravemeijer, S. McKenney, \& N. Nieveen (Eds.), Educational design research (pp. 67-90). New York: Routledge.

Meijers, F., \& Wardekker, W. (2001). Ontwikkelen van een arbeidsidentiteit. In J. W. M. Kessels \& R. F. Poell (Eds.), Human resources development: Organiseren van het leren (pp. 301-317). Alphen aan den Rijn: Samsom.

Mentkowski, M., Rogers, G., Doherty, A., Loacker, G., Hart, J. R., Rickards, W., et al. (2000). Learning that lasts: Integrating learning, development, and performance in college and beyond. San Francisco: Jossey-Bass.

Nonaka, I., \& Takeuchi, H. (1995). The knowledge-creating company: How Japanese companies create the dynamics of innovation. New York: Oxford University Press.

Paavola, S., Lipponen, L., \& Hakkarainen, K. (2004). Models of innovative knowledge communities and three metaphors of learning. Review of Educational Research, 74(4), 557-576.

Pekrun, R., \& Linnenbrink-Garcia, L. (2012). Academic emotions and student engagement. In S. L. Christenson, A. L. Reschly, \& C. Wylie (Eds.), Handbook of research on student engagement (pp. 259-282). New York: Springer.

Poortman, C. L. (2007). Workplace learning processes in senior secondary vocational education. Enschede, The Netherlands: Universiteit Twente.

Rogoff, B., Matusov, E., \& White, C. (Eds.). (1996). Models of teaching and learning: Participation in a community of learners. Oxford: Blackwell.

Rubin, H. J., \& Rubin, I. S. (2006). Qualitative interviewing: The art of hearing data. Thousand Oaks, CA: Sage. 
Sandoval, W. (2014). Conjecture mapping: An approach to systematic educational design research. Journal of the Learning Sciences, 23(1), 18-36.

Savin-Baden, M., \& Howell Major, C. (2010). New approaches to qualitative research: Wisdom and uncertainty. Berkshire, UK: Open University Press.

Sawyer, R. K. (2004). Creative teaching: Collaborative discussion as disciplined improvisation. Educational Researcher, 33(2), 12-20.

Scardamalia, M., \& Bereiter, C. (1993). Computer support for knowledge-building communities. Journal of the Learning Sciences, 3(3), 265-283.

Schön, D. A. (1987). Educating the reflective practitioner. San Francisco: Jossey-Bass.

Senge, P. M. (1990). The fifth discipline: The art and practice of the learning organization. New York: Random House.

Sfard, A. (1998). On two metaphors for learning and the dangers of choosing just one. Educational Researcher, 27(2), 4-13.

Strauser, D. R., Lustig, D. C., \& Çiftçi, A. (2008). Psychological well-being: Its relation to work personality, vocational identity, and career thoughts. The Journal of Psychology, 142(1), 21-35.

Thompson, N., \& Pascal, J. (2012). Developing critically reflective practice. Reflective Practice: International and Multidisciplinary Perspectives, 13(2), 311-325.

Tynjälä, P. (1999). Towards expert knowledge? A comparison between a constructivist and a traditional learning environment in the university. International Journal of Educational Research, 31(5), $357-442$.

Tynjälä, P. (2008). Perspectives into learning at the workplace. Educational Research Review, 3(2), $130-154$.

Tynjälä, P. (2009). Connectivity and transformation in work-related learning: Theoretical foundations. In M.-L. Stenström \& P. Tynjälä (Eds.), Towards integration of work and learning (pp. 11-37). Dordrecht: Springer Science + Business Media.

Tynjälä, P., Välimaa, J., \& Sarja, A. (2003). Pedagogical perspectives on the relationships between higher education and working life. Higher Education, 46(2), 147-166.

Van den Akker, J. (2003). Curriculum perspectives: An introduction. In J. Van den Akker, W. Kuiper, \& U. Hameyer (Eds.), Curriculum landscapes and trends (pp. 1-10). Dordrecht: Kluwer Academic Publishers.

Van den Akker, J., Gravemeijer, K., McKenney, S., \& Nieveen, N. (Eds.). (2006). Educational design research. New York: Routledge.

Van Merriënboer, J. J. G., \& Sluijsmans, D. M. A. (2009). Toward a synthesis of cognitive load theory, fourcomponent instructional design, and self-directed learning. Educational Psychology Review, 21(1), 55-66.

Walker, D., \& Nocon, H. (2007). Boundary-crossing competence: Theoretical considerations and educational design. Mind, Culture, and Activity, 14(3), 178-195.

Wals, A. E. J. (1994). Pollution stinks: Young adolescents' perceptions of nature and environmental issues with implications for education in urban settings. De Lier: Academic Book Center.

Wals, A. E. J., \& Alblas, A. H. (1997). School based research and development of environmental education: A case study. Environmental Education Research, 3(3), 253-267.

Wals, A. E. J., Lans, T., \& Kupper, H. (2012). Blurring the boundaries between vocational education, business and research in the agri-food domain. Journal of Vocational Education, and Training, 64(1), $3-23$.

Wesselink, R., Dekker-Groen, H. M., Biemans, H. J. A., \& Mulder, M. (2010). Using an instrument to analyse competence-based study programmes: Experiences of teachers in Dutch vocational education and training. Journal of Curriculum Studies, 42(6), 813-829.

Wierenga, E. M. W., Cremers, P. H. M., Hekman, E. G. A., \& Buikema, H. (2010). Value in the Valley, het leerarrangement in de praktijk. Groningen: Value in the Valley.

Zegwaard, K. E., \& Coll, R. K. (2011). Exploring some current issues for cooperative education. Journal of Cooperative Education and Internship, 45(2), 8-15.

Zitter, I. (2010). Designing for learning: Studying learning environments in higher professional education from a design perspective. Utrecht: Universiteit Utrecht.

Zitter, I., \& Hoeve, A. (2012). Hybrid learning environments: Merging learning and work processes to facilitate knowledge integration and transitions (OECD Education Working Papers 81). Paris: OECD Publishing. 